\title{
Mehmed İzzet ve Mehmed Ali Aynî Arasında İçtimaiyat Dersleri Üzerine Bir Polemik
}

\author{
DOI: 10.26466/opus.590531
}

\author{
$*$ \\ Yeliz Okay* \\ *Dr., Bağımsız Araştırmacı \\ E-Posta: yelizakinokay@gmail.com \\ ORCID: 0000-0001-8868-9436
}

Öz

1913 yılında İstanbul Darülfünun'unda Ziya Gökalp'ın öncülüğünde ders olarak okutulmaya başlanan Sosyoloji(İçtimaiyat)'nin zaman içinde ders kitapları da yayımlanmaya başlamıştır. Bunlar içinde hem telif hem de tercüme olan kitaplar bulunmaktadır. Cumhuriyet'in ilaninın hemen ertesinde yayımlanan ilk Sosyoloji ders kitaplarnndan biri de Paris'teki Sorbonne Üniversitesi'nde Felsefe bölümünde okuyan Mehmed İzzet tarafindan tercüme edilen İçtimaiyat Dersleri başlıklı eserdir. Eser, sosyoloji eğitimi tarihi açısından çevrilen Cumhuriyet döneminin ilk genel sosyoloji ders kitablarından biri olma özelliği ile önplana çlkar.Sosyoloji terimlerinin Türkçelleştirilmesinde de öncü olan Ziya Gökalp, Mehmed İzzet'in bu kitabinda faydalandığı isim olmuştur. Ancak yine terimlerin Türkçe'leştirilmesi üzerinde çalışmalar bulunan Mehmed Ali Aynî Içtimaiyat Dersleri kitabının tercümesi ile ilgili olarak bir eleştiri yazısı kaleme almıştır. Mihrap Mecmuası'ndsa çıan bu makaleye Mehmed İzzet Millî Mecmua'da cevap vermiştir. Osmanlı Devleti'nin son döneminde yetişmiş ve dolayısıyla erken Cumhuriyet döneminin de ilk aydınları arasında yer almış bu iki kişinin bir Sosyoloji ders kitabı üzerinden yürüttükleri polemik bu alanda ilk polemiklerden biri olduğu için dikkate değerdir.

Anahtar Kelimeler: $\quad$ Mehmed İzzed, Mehmet Ali Ayni, Içtimaiyat Dersleri 


\title{
A Polemics Between Mehmed İzzet and Mehmed Ali Aynî About The Book: İçtimaiyat Dersleri
}

\begin{abstract}
In this In 1913, under the leadership of Ziya Gökalp in Istanbul Darülfünun began to be taught as a course Sociology (Ictimaiyat) the course books began to be published. These books are both translated and written by Turkhis authours. Immediately after the proclamation of the Republic, one of the first Sociology textbooks published by Mehmed Izzet was titled Lessons of Sociology Ziya Gökalp, who was a pioneer in the translation of the terms of sociology, was the author, Mehmed İzet used in this book. However, Mehmed Ali Aynî, who has also worked on the translation of the terms, wrote a critique about the translation of the book Ictimaiyat Dersleri in Mihrab Mecmuası. Mehmed Izzet responded to this article in Milli Mecmua. The polemic carried out by these two people, who were brought up in the last period of the Ottoman Empire and thus were among the first intellectuals of the early Republican period, is remarkable since it is one of the first polemics in this field.
\end{abstract}

Keywords: Habitus; Cultural Reproduction; Social Reproduction; Studentship 


\section{Giriş}

1913 yılında Üniversite'de ders olarak okutulmaya başlanan Sosyoloji(İçtimaiyat)'nin zaman içinde ders kitapları da yayımlanmaya başlamıştır. Bunlar içinde hem telif hem de tercüme olan kitaplar bulunmaktadır. Cumhuriyet'in ilanının hemen ertesinde yayımlanan ilk Sosyoloji ders kitaplarından biri de Mehmet İzzet tarafında tercüme edilen İçtimaiyat Dersleri başlıklı eserdir.

Mehmed İzzet(1891-1930) Galatasaray Lisesi'ni bitirmiş daha sonra burslu olarak gittiği (Topaloğlu, 2003, s.492) Paris Sorbon Üniversitesi'ndeki eğitimini büyük bir ihtimalle tamamlamadan(Değirmencioğlu, 1987: s:28) Türkiye'ye dönmüş değişik görevlerde bulunduktan sonra bu çalışmaya konu olan kitabı yayımladığı yıl olan 1924'te Darülfünun'da Felsefe, Ahlâk ve Sosyoloji dersleri vermiştir(Topaloğlu, 2003, s.493).

Mehmed İzzet'in 1924 yılında, İkinci Heyet-i İlmiye Kongresi'nde alınan Sosyoloji' nin orta dereceli okullarda ders olarak okutulması kararı üzerine(Sain, 2018, s.80) tercüme ederek yayımladığı kitabın başlığı Terbiye ve Ahlâka Müteallik Tatbikatiyle İçtimaiyat Dersleri başlığını taşımaktadır. "İstanbul Darülfünunu Edebiyat Fakültesi Neşriyatı'ndan" olan kitabın yazarları kapakta yer alan bilgiye göre Aix Erkek Muallim Mektebi Müdiri A. Gleyse ve Fransa Sanayi Mekteblerinde İktisat Tarihi Muallimi A. Hesse'dir. Matbaa-i Âmire'de basılan kitap 325 sayfadır*. Bir el kitabı olarak hazırlanan kitabın orijinal ismi Notion de Sociologie'dir.(Topaloğlu, 2003, s.493) İ.Ü. Edebiyat Fakültesi'nin 1 no'lu yayını olan bu eser Sosyolojinin konusunun ne olduğundan başlayarak, toplum- birey ilişkisi, toplumların tasnifi, sosyolojinin alt alanları, devlettoplum ilişkisi, ulusun oluşumu ve özellikleri, din sanat, aile gibi konular Durkheim sosyolojisi yaklaşımı içinde alınıp, açıklığa kavuşturulmak istenmiştir (Sosyoloji Araştırma Merkezi, 1999, s.9).

'Mütercimin Mukaddimesi'nde Mehmed İzzet Türkçe'de Sosyoloji ile ilgili ders kitabının olmamasının büyük bir eksiklik olduğunu, tercüme ettiği bu kitabın Fransa'da yazılan benzer kitaplar arasında en iyisi olduğunu ve içerik ve düzeniyle de öne çıktı̆̆ını belirtir.(Mehmed İzzet, 1924a). Kitapta yazarların Durkheim ekolüne 'fazla merbut(bağl1)' kaldığını da itiraf eden Mehmed İzzet buna karşılık kitabın Sosyoloji'nin araştırma alanlarının geniş bir şekilde kapsadığını ancak kitabın, tama- 
men Fransa toplumu göz önüne alınarak kaleme alınmış olduğu hâlde yine de Darülfünun öğrencilerinin 'böyle bir rehbere ihtiyacı' olduğunu gördüğü için tercüme etmeye karar vermiş olduğunu ifade eder. Tercüme yöntemi ile ilgili olarak da orijinal metinde giriş kısmında yer alan bazı kısımları tercüme etmediğini ancak asıl metinle ilgili olarak herhangi bir çıkarma ya da ekleme yapmadığını ifade eder. Felsefe terimleri için Maarif Istılahat Komsiyonu'ndan ve Sosyoloji terimleri için de Ziya Gökalp'tan faydalandığını iktisat ve hukuk için terimleri için ise 'salahiyetdar müderrislere müracaat' ettiğini vurgulayan Mehmed İzzet "buna rağmen gerek tercüme kusuru gerek tertib sehvi olarak birçok yanlışların kalmış olması muhtemeldir" demektedir.(Mehmed İzzet, 1924, s.b-c). Kitabın ana bölümleri de Medhal(giriş), İktisadî İçtimaiyat, Beytî İçtimaiyat, Siyasî İçtimaiyat, Cinâî İçtimaiyat, Din-İlim ve Sanatın Menşei ve Münasebatı'nden oluşmaktadır. Kitabın sosyoloji tarihi açısından önemli özelliklerinden biri yayımlandığı dönemde I. Dünya Savaşı'nın sona ermiştir ve Sosyoloji merkezli toplumsal sorunlara çözüm arama yaklaşımının yerini Sosyoloji'nin artık toplumla ilgili bilgileri öğreten bir bilim olarak varlığını sürdürmeye başlamasının almış olduğu gerçeğidir (Sosyoloji Araştırma Merkezi, 1999, s.8). Bu anlamda Mehmed İzzet, Ziya Gökalp'in aksine toplumsal sorunlara Sosyolojinin imkanları ile çözüm arayan, doktrin sahibi aynı zamanda siyasetçi sosyolog kimliğinden bağımsız disiplini toplumu izah etmeye çalışan bir bilim olarak yorumlaması yönüyle de önemlidir. Bu sebeple Mehmed İzzet İçtimaiyat Dersleri'nin sosyoloji ve terminolojisi ile toplum konusuna odaklı bir nitelikte genel sosyoloji ders kitabı olmasını sosyoloji eğitimi açısından önemsemiştir. Mehmed İzzet'in tercüme ile ilgili açıklamalarına karşılık Mihrab mecmuasında, bu kitabı özellikle tercüme yönünden eleştiren Mehmed Ali Aynî(1869-1945)'nin yazısının başlığı da Mehmed İzzet'in kitabını adını taşımaktadır. İçtimaiyat Dersleri.

Mülkiye Mektebi'nden 1888'de mezun olan Mehmed Ali Aynî değişik eğitim kurumlarında çalıştıktan sonra Balıkesir ve Lazkiye Mutasarrıflığ1, Yanya ve Trabzon Valilikleri'nde bulundu. 1914'ten itibaren Darülfünun'da Felsefe derslerini okutmaya başlayan Aynî ertesi Edebiyat Fakültesi Müderrisler Meclisi Reisi oldu.(Arar, 1991, s.273). Arar'a göre(1991, s.274) Aynî Franszıca'dan yapılan tercümelerdeki felsefî terimlerin düzeltilmesi konusunda makaleler kaleme almıştır. 


\section{İçtimaiyat Dersleri Üzerine Bir Polemik}

Millî Mecmua'daki yazısına "Bugünlerin en mühim hadise-i ilmiyesi, benim nazarımda İçtimaiyat Dersleri unvanlı kitabın tercüme ve neşredilmiş olmuştur" diyerek başlayan (Aynî, 1340, s.705) Mehmed Ali Aynî kitabın 'tercüme' olduğunu israrla yazısının tamamında vurgular."Darülfünun müderrislerinden İzzet Beyefendi'nin güzide-i kalemiyesine medyun olduğumuz bu kitap cidden bir hazine-i maariftir" (Aynî, 1340, s.705) cümlesiyle yine yazının tamamına hâkim olacak alaycı üslubunu da sergilemeye başlar.

Ayni'ye göre yeni bir ilim olan İçtimaiyat onbeş yıldır okulların programına girmiş olmasına rağmen henüz bir ders kitabının olmadığı, dolayısıyla 'müderris-i muhteremin'in yaptığı hizmetin her bakımdan takdire değer bulunduğunu, sosyal olayların ortaya çıkışı ve takip ettiği akımlar hakkında artık bilgi sahibi olunabilecek bir kaynağa sahip olunduğunu vurgular.Ancak yazar gazete sütunlarında sporla ilgili lüzumsuz birçok haber yer aldığını buna karşılık bu kitapla ilgili 'ücretle yazdırılmış birkaç satırlık ilan dışında' bir şey görülmediğini kendisinin de bazı eleştirilerini 'mütercim-i muhteremin nazar-1 tedkikine arz' edeceğini belirtir. (Aynî, 1340, s.705)

Aynî ilk olarak tercümelerin aynen ve harfiyen yapılması münasip ise de bu tercümenin biraz acele yapıldığı izlenimini aldığını söyler. Halbuki 'bu kıymetli kitabın daha ziyade dikkat ve itina'ya muhtaç olduğunu da iddia eder. İkinci olarak kitabın ilk sayfalarında harfiyen tercümeye itina gösterildiği hâlde ilerleyen sayfalarda bu konun geri plana itildiği hatta bazı yerlerde 'ilavelere' bile başvurulduğu ifade eder(Aynî, 1340, s.705).

Aynî Örnek olarak L'à de la pierre éclatée ibaresinin yanlış çevrildiğini teferruatlı bir biçimde açıklar ve taş devri başta olmak üzere tarih öncesi devirlerin nasıl tercüme edilmesi ve isimlendirilmesini gereğini üzerinde durur. (Aynî, 1340: s.706) "Par nécessité ne demektir ?" başlı̆̆1 altında "İnsan içtmâî bir hayvandır. Hiçbir tarif bu tariften daha doğru olmamıştır. İnsan sade ızdırarî olarak içtmâî değildir" cümle dizisinde geçen '1zdıraî olarak' ibaresini asıl metinden geçen 'par nécessité' yerine kullanıldığını halbuki 'zaruret ve ihtiyaç sevkiyle' tercümesinin daha 
yerinde olacağını belirtir. (Burada Aynî müstehzi bir dille kendisinden 'bendeniz' olarak söz eder). (Aynî, 1340, s.707)

Benzer şekilde esas metinden yola çıarak 'établir', 'parquer', 'précis', 'clarté', 'intution', 'fédération' gibi kelimelerin Mehmed İzzet tarafından nasıl -yanlış- tercüme edildiğini ve kendi cümleleriyle nasıl tercüme edilmesi gerektiğini gösterir. (Aynî, 1340: ss.707-708) Mehmed Ali Aynî bunların arkasından orijinal kitapta yer alan onbir satırlık bir metni Latin harfli şekli ile olduğu gibi vererek hemen her satır ve kelimesinin nasıl yanlış tercüme edildiğini gösterir ve yazısını 20 Eylül 340/1924 Kızıltoprak yazarak bitirir. (Aynî, 1340, s.708-710)

Görüldüğü gibi Mehmed Ali Aynî'nin eleştiri yazısı tamamen Fransızca'dan yapılan tercümenin eksik ya da yanlışlıkları ile ilgilidir ve zaman zaman da alaycı bir üslup kullanarak Mehmed İzzet'i tenkit etmiştir. Bu yazıya Mehmed İzzet Millî Mecmua'da karşlık vermiştir. Hilmi Ziya Ülken Mehmed İzzet'in, 'haşin ve sinirli kendisini savunmaya ve bazı noktalarda kendini mazur göstermeye çalıştığını' yazmış(Ülken, 1979, s:436) ama bu savunmayı nerede yaptı̆̆ına dair kaynak belirtmemiştir. Mehmed İzzet de benzer bir alaycı üslubu benimsemiş ve bunu daha başlıkta belli etmiştir:

“Bir Lütüfkâr Münekkide Cevap. 'Millî Mecmua Müdiriyetine' hitaben yazılan ve 'Müdir Bey' hitabıyla bir mektup tarzında başlayan yazı “Mihrab Mecmuası'nın Teşrin-i Evvel 1340 tarihli nüshasında Mehmed Ali Beyefendi'nin benim tercüme eylediğim İçtimaiyat Dersleri kitabına aid bir tenkitnâmesi intişar eylemiş. İlahiyat medresesi müderrisinin vukuf ve salahiyet-i kâmilesine binâen pek mühim olması lâzım gelen bu makaleyi derhal okumaklığım iktiza ederdi. Maateessüf geç haberdar oldum. Bundan dolayı cevap vermekte geç kaldım. Mecmuanızın bir köşesinde bu cevabımın, uzunca olmasına rağmen, derc edileceğini lütufkârlığınızdan beklemekteyim." cümleleri ve alaycı üslubu ile devam eder.(Mehmed İzzet, 1340, s.416)

“Cevap vermek istiyorum. Fakat nasıl vereyim? Müşkilim var. Mehmed Ali Beyefendi beni bir taraftan lâyık olmadığım iltifata mazhar diğer taraftan da yine müstahak olduğumu hiç zannetmediğim tenkidata duçar kılmış” diyerek müstehzi yaklaşımını sürdüren Mehmed İzzet. (Mehmed İzzet, 1340, s.416), 'alelade bir mektep kitabını' tercüme ederek 'ufak' bir hizmet yaptığını ve -gene alaycı bir üslupla- Aynî'nin 
kendisini teşvik etmek istediğini ancak esere 'tamamen kusursuzdur' dememek için en 'hafif kusurları' seçerek 'kolay muzafferiyet sağlayacak' yolu tercih ettiğini iddia eder. Kitabın 165-225 sayfalarını tercüme etmek üzere bir kişiye verdiğini ancak bu kişinin son anda vazgeçince kendisinin hızla tercüme etmek zorunda kaldığını, ancak 'itinasız ve dikkatsiz' tercüme edildiğini şiddetle reddettiğini belirtir. (Mehmed İzzet, 1340, s.416)

Bütün kitapta sadece iki cümleyi içine sinmeden tercüme ettiğini açıklayan Mehmed İzzet bazı kelimelerin kendisinin müsveddelerde yazdığı gibi basılmadığını dolayısıyla 'mürettib' hatası olduğunu, 'par nécessité' meselesinde kitap yeniden basılsa dahi buradaki tercümesini değiştirmeyeceğini ve diğer kelimeler için de 'dayanamıorum', 'insaf olunsun', "haksızlık ediliyor' gibi ibarelerle kendisine haksızlık yapıldığını belirtir. (Mehmed İzzet, 1340, s.419-421). Mehmed İzzet yazısının sonunda makale boyunca sık sık tezyif amaçlı kullandığ 'ilahiyat müderrisi' tabirine bir karşılık olarak 'Darülfünun Ahlâk Müderrisi" imzasını kullanır.

\section{Sonuç}

Galatasaray Lisesi'nden mezun olup Sorbon'da felsefe eğitimi alan Mehmed İzzet önceleri Ziya Gökalp'ın ve dolayısıyla onunda izinden gittiği Dukheim'ın yolundan gitmiş ancak daha sonra zamanla kendine özgü bir sosyolojik anlayış geliştirmiştir (Topaloğlu, 2003, s.492). Yaptığ tercümelerle hem Sosyoloji'nin hem de Ahlâk ve Felsefe'nin Türkiye'de tanınması ve yayılmasına katkı sağlayan Mehmed İzzet'in bu tercümeleri zaman zaman eleştiriye de uğramıştır. Mehmed Ali Aynî'nin Mihrab Mecmuası'ndaki tercüme temelli eleştirisine Mehmed İzzet Millî Mecmua'da cevap vermiştir. Sosyoloji terminolojisin nasıl oluşturulacağı ve sosyolojik çevirinin nasıl yapılması gerektiğine dair iki entelektüelin giriştikleri polemik, Cumhuriyet tarihinde sosyoloji disiplini çerçevesindeki polemiklere öncü olması açısından ayrı bir değer taşımaktadır. 


\title{
EXTENDED ABSTRACT
}

\section{A Polemics Between Mehmed İzzet and Mehmed Ali Aynî About The Book: İçtimaiyat Dersleri}

\author{
Yeliz Okay \\ Independent Researcher
}

Sociology was started to be taught as a course at the University in 1913 and textbooks of the university began to be published. These include books that are both copyrighted and translated. Immediately after the proclamation of the Republic, one of the first Sociology textbooks was published by Mehmet İzzet, entitled İçtimaiyat Lessons.

Mehmed Izzet (1891-1930) and graduated from Galatasaray High School and then went on a scholarship in Paris before completing his education at the Sorbonne University, probably returned to Turkey different in 1924, the year in which he published the book which was the subject of this study, he taught Philosophy, Morality and Sociology at Darülfünun. Mehmed İzzet's decision to teach Sociology as a course in secondary schools, which was taken at the Second Committee of Science Congress in 1924 , was translated in to Turkish. . According to the information on the cover, the authors of the book are A. Gleyse, the director of the Aix School of Male Teachers and A. Hesse of the History of Economics in the French Industrial Schools. The book published in Matbaa-i Amire is 325 pages . The original name of the book prepared as a handbook is Notion de Sociologie . In contrast to Mehmed İzzet's explanations about translation, the title of Mehmed Ali Aynî (1869-1945), who criticized this book especially in terms of translation, is named as Mehmed İzzet's book.

Mehmed Ali Aynî, who graduated from the Faculty of Political Sciences(Mekteb-I Mülkiye-I Şahane) in 1888, worked in various educational institutions and then he worked in the Governorships of Balıkesir and Lazkiye Districts, the Governors of Ioannina and Trabzon. In 1914, he started to teach philosophy courses at Darülfünun (İstanbul University). In the following year, he became the Chairman of the Board of Directors of the Faculty of Letters(Müderrisler Meclisi Reisi). According to Arar (1991, p. 274), he wrote articles on the correction of philosophical terms in translations from the same French. 
According to Mehmed Ali Ayni, İctimaiyat(Sociology), which is a new science, has been in the program of the schools for fifteen years, yet there is no textbook, so the service of the 'esteemed professor" is admirable in all respects, and there is now a source of information about the emergence of social events and the currents it follows. However, there are many unnecessary sports news in the newspaper columns, however, this book 'about a few lines of the printed fee, except for a few lines of adverts' is not seen anything in his own criticism of the 'interpreter of the interrogation of the supply' will specify.

In the first place, it is appropriate for the translations to be done exactly and literally, but Mehmed Ali Ayni says that he got the impression that this translation was done in a bit of a hurry. However, he also argues that this precious book is in need of attention and care. Secondly, although the first pages of the book have been meticulously translated, the following pages indicate that this issue has been pushed to the background and even some additions have been resorted to in some places.

As seen, Mehmed Ali Aynî's criticism is entirely related to the incomplete or inaccuracy of the French translation, and he often criticized Mehmed İzzet, using a cynical style. Mehmed İzzet responded to this article in Milli Mecmua(National Journal). Hilmi Ziya Ülken wrote that Mehmed İzzet was 'harsh and frustrated trying to defend himself and to excuse himself at some points but he did not mention the source of his defense.

In the book, Mehmed Izzet, who admits that the authors remained too loyal to the school of Durkheim, on the other hand, found that the book covers a wide range of Sociology's research areas, but that the Darulfünun's students still needed 'such a guide', even though the book was entirely taken into account by French society. to translate for. Regarding the translation method, it does not translate some parts of the original text in the introduction, but does not make any subtraction or additions to the original text.

After graduating from Galatasaray High School and studying philosophy at the Sorbonne, Mehmed İzzet followed the path of Ziya Gökalp and Dukheim, which he followed in his footsteps; both with his translation of Sociology and Philosophy both morality that contribute to recognition and spreading in Turkey Mehmed Izzet has undergone criticism from time to time these translations. Mehmed Ali Aynî's translation-based criticism in Mihrab Mecmuası Mehmed İzzet responded to Milli Mecmua. The polemics 
of the two intellectuals about how to establish the terminology of sociology and how sociological translation should be carried out have a distinct value in terms of being the pioneer of the sociology discipline in the history of the Republic.

\section{Kaynakça / References}

Arar, İ. (1991), Mehmed Ali Aynî. Türkiye Diyanet Vakfı İslam Ansiklopedisi, içinde (273-274), 4.Cilt.

Değirmencioğlu, M. C.(1987). Mehmed Izzet. Kültür Bakanlığı: Ankara.

Aynî, M. A. (1924). İçtimaiyat Dersleri. Mihrab, N:21-22, , ss:705-710

Mehmed İzzet (1924). Bir lütüfkâr münekkide cevap. Millî Mecmua, N:26, 416-421.

Mehmed İzzet (1924a). İçtimaiyat Dersleri. (A.Gleyse-A.Hesse),(Haz. M. Kanar) İstanbul Darülfünunu. Matbaa-i Amire.

Sain, K.(2018). Cumhuriyet dönemi lise sosyoloji ders kitaplarında ideolojik içerik. Yüksek Lisans Tezi, Gazi Üniversitesi. Ankara.

Topaloğu, A.(2003). Mehmed İzzet. Türkiye Diyanet Vakfi İstanbul Ansiklopedisi. içinde (s.492-493), Ankara.

Ülken, H.(1979). Türkiye'de çă̆gaş düşünce tarihi. İstanbul: Ülken Yayınları

\section{Kaynakça Bilgisi / Citation Information}

Okay, Y. (2019). Mehmed İzzet ve Mehmed Ali Aynî arasında İçtimaiyat Dersleri üzerine bir polemik. OPUS-Uluslararası Toplum Araştırmaları Dergisi, 13(19), 2653-2662. DOI: 10.26466/ opus. 590531 